\title{
CRISTOLOGiA
}

\section{NO Relato dA PAIXÃo SEgundo MARCOS $(14,1$ - 16,8): SOB O PONTO DE VISTA DO NARRADOR}

\author{
CHRISTOLOGY \\ IN the Report of the PAssion According to MARK (14.1 to 16.8): \\ FROM THE NARRATOR'S POINT OF VIEW
}

JUNIOR VASCONCELOS do AMARAL ${ }^{(*)}$

\begin{abstract}
RESUMO
Este artigo tem como finalidade identificar o ponto de vista do narrador da Paixão de Jesus em Marcos $(14,1-16,8)$. O ponto de vista constitui todos os expedientes narrativos, seja antropológico, social, geográfico e teológico que perpassam o horizonte do narrador de Marcos e formam o escopo e significado da cristologia na Paixão de Jesus. A cristologia, por sua vez, consiste no modo como Jesus se revela nas cenas derradeiras do Evangelho de Marcos, nos momentos decisivos de sua vida, que tem como culminância a Paixão e entrega na cruz do Calvário em vista da Ressurreição. Portanto, o ponto de vista do Evangelho de Marcos centraliza-se nas figuras do Filho de Deus e Filho do Homem.
\end{abstract}

Palavras-Chave: Evangelho de Marcos. Ponto de vista. Paixão. Morte. Cristologia.

\section{ABSTRACT}

The aim of this article is to identify the point of view of the narrator of the Passion of Jesus in Mark (14.1 to 16.8). This point of view comprises all the expedients of the narrative: anthropological, social, geographical and theological that pervade the horizon of Mark's narrator and form the scope and meaning of Christology in the Passion of Jesus. Christology in turn is the way Jesus reveals himself in the final scenes of Mark's Gospel, in the decisive moments of his life, the culmination of which is the passion and the acceptance of the cross on Calvary in view of the Resurrection. Therefore, Mark's Gospel point of view centers on the figures of the Son of God and the Son of Man.

KEYWORDS: Gospel of Mark. Point of view. Passion. Death. Christology.

\section{INTRODUÇÃO}

Para a narratologia bíblica moderna, "o ponto de vista do narrador, corresponde aos seus pressupostos ideológicos e sua escala de valores" (VITÓRIO, 2016, p. 133), e pode ser considerado um componente importante na arte de narrar um acontecimento. Os pontos de vista da narrativa de Marcos, que permeiam e dão sentido ao Evangelho, podem ser percebidos como

\footnotetext{
(*) Doutor em Teologia Sistemática pela FAJE/BH (Faculdade Jesuíta de Filosofia e Teologia), membro do Grupo de estudos Bíblia em leitura cristã, vinculado à CNPq, professor de Teologia no Instituto Dom João Resende Costa, na PUC-Minas. Belo Horizonte - MG - Brasil. E-mail: jvsamaral@yahoo.com.br.
} 
apresentados pelo narrador, atendendo aos diálogos, às ações, às características embutidas naquilo que os personagens dizem e fazem, bem como em seus pensamentos e sentimentos internos, assim como sua posição na sociedade, representada no relato.

O intuito deste artigo consiste em observar e elencar alguns pontos de vista na narrativa da Paixão segundo Marcos $(14,1$ - 16,9), a saber: o ponto de vista acerca do Filho de Deus e Filho do Homem, seguido da perspectiva do Reino de Deus, ou soberania divina. Outros pontos de vista importantes são o final aberto de Marcos $(16,8)$, assim como o ponto de vista da Galileia, da diakonia ou serviço prestado a Jesus, o ponto de vista do feminino no decorrer da narrativa como um todo e, por fim, a cristologia de Marcos à luz da teologia do servo sofredor de Isaías.

\section{PONTO DE VISTA NA PAIXÃo DE JESUS}

No que se refere ao relato da Paixão (Mc 14,1 - 16,8), os pontos de vista do narrador estão relacionados ao personagem protagonista da Paixão, Jesus, o Filho de Deus (cf. Mc 1,1; 15,39). Ele é um homem de fé que entrega (em grego: didōmi) sua própria vida no Calvário, assumindo, plenamente, a vontade de Deus. Com isso, Jesus se identifica com a soberania de Deus e, consequentemente, se constitui aquele que vem servir e não ser servido, horizonte este que tem como ponto convergente Mc 10,45. Perdendo sua vida na cruz, Jesus ganha, da parte de Deus, a fiabilidade total - sua filiação é plena e, por isso, Jesus será ressuscitado dos mortos. Da parte dos homens, as autoridades judaicas se tornam veementemente hostis a Jesus; isto pode ser observado desde Mc 2,7, (episódio da cura do paralítico, na qual os escribas afirmam que Jesus estava blasfemando), tendo como momento decisivo Mc 3,6 (versículo final da cura do homem da mão atrofiada, em dia de sábado, no qual os fariseus e herodianos tomaram a decisão de eliminar Jesus), restando identificá-los com a falta de fé, o medo em relação ao que Jesus poderia fazer frente à estabilidade da religião judaica no I século e o modo como ele viveu a religião (cf. Mc 12,12), libertando as pessoas de toda opressão (Mc 3,22) e desestabilizando a presunção daqueles que detinham o exercício do poder.

Já no relato da Paixão, tais questões podem ser observadas em dois momentos, conexos a todo o Evangelho. Primeiro, em Mc 14,61-63, em que Jesus é questionado pelo sumo sacerdote sobre sua identidade: "Tu és o Cristo, o Filho do Bendito?”; pergunta à qual Jesus responde: "Sou eu, e vereis o Filho do Homem assentado à direita do poder e vindo com as nuvens do céu”. Depois 
dessa resposta acintosa, o sumo sacerdote rasga suas vestes em gesto reprovador das palavras de Jesus, que pareceu ferir, com elas, sua fé messiânica, que não via nele o Filho de Deus. A resposta de Jesus parece desestabilizar a compreensão de fé do sumo sacerdote, que representava, de forma ordinária, a fé judaica. Em seguida, em Mc 15,2-5, há a passagem na qual Pilatos questiona Jesus se ele era mesmo o rei dos judeus, recebendo a resposta: "Tu o dizes". Os sacerdotes chefes o acusaram de muitas coisas; Pilatos redarguiu, dizendo: "Não respondes nada? Olha de quantas coisas te acusam?!” Jesus, contudo, nada respondeu, fazendo Pilatos se admirar (Mc 15,5). A admiração de Pilatos e o silêncio de Jesus são ironias do narrador de Marcos: a autoridade hegemônica de Pilatos é destituída e relativizada pelo silêncio ensurdecedor de Jesus. A presunção do Procurador Romano, de saber tudo, pela autoridade que exercia, cai por terra mediante o silêncio de Jesus, que revela o mistério de Deus em sua vida. Assim, Jesus responde silenciosamente, pois seu poder primacial vinha do Pai, de Deus mesmo.

\section{Filho de Deus E FILHo do HomeM}

O ponto de vista teológico Filho de Deus e Filho do Homem consistem em dois títulos cristológicos que sobressaem na narrativa de Marcos.

O primeiro título, Filho de Deus, está presente, sobremaneira, na culminação do relato da Paixão (Mc 15,39). Na abertura do relato marcano, em Mc 1,1 o título "Filho de Deus" já constitui uma informação fornecida ao leitor, embora seja incerta essa afirmação do ponto de vista da crítica textual, que não se encontra presente em todos os manuscritos antigos do NT (SEGALLA, 1992, p. 77). Assim, essa informação "permanece escondida para os personagens que aparecem progressivamente na narração" (VAN OYEN, 2011, p. 111): os discípulos, a família de Jesus, os adversários. Só os leitores são colocados a par da opinião de Marcos sobre a filiação divina de Jesus. Apenas os demônios são capazes de revelar quem é Jesus $(1,24-25 ; 3,12)$. É curioso perceber que os demônios têm uma presciência em relação a Jesus, conforme descrito em Mc 1,24, quando o espírito impuro diz: "Sei quem tu és: o Santo de Deus”. Já em Mc 3,12, se diz que os espíritos impuros caíram aos pés de Jesus e gritaram: "Tu és o Filho de Deus”. Jesus, porém, ordenava-lhes silêncio. Em Mc 5,6, o espírito impuro, ao ver Jesus de longe, correu e ajoelhou-se diante dele e clamou em alta voz: “Que queres de mim, Jesus, Filho do Deus altíssimo?” Vale lembrar que em 
alguns relatos apócrifos, como no caso o Testamento de Salomão, os demônios são portadores de presciência, sabendo o que virá (VAN OYEN, 2011, p. 11)².

Em Mc 1,11, da mesma forma que Mc 9,7, tratam-se, o batismo e a transfiguração, de expressões teofânicas, nas quais Jesus é revelado pelo Pai como o Filho amado - em grego ó uiós mou ó agapetós. O título cristológico nessas duas cenas tem em comum com Filho de Deus apenas o termo Filho, uiós, que pode ser considerada a base fontal que relaciona Jesus àquele que o enviou, o Pai.

No caso de Marcos, em alguns momentos o leitor percebe que Jesus não desejava ser reconhecido como Filho de Deus, mas como Filho do Homem. Estes dois títulos, portanto, estão alocados sob a noção do segredo messiânico (Mc 1,34.44-45; 3,11; 5,43; 7,36; 9,9). J. Gnilka recomenda chamar de "segredo do filho de Deus" (GNILKA, 1986. p.198.), pois a acepção da filiação divina é muito cara a Marcos. Por outro lado, Elizabeth Struthers Malbon propõe uma "Cristologia do desvio" (deflected Christology), na qual Jesus se esforça para reorientar a honra, o respeito e a atenção de seus interlocutores para Deus, retirando de si a atenção dos circunstantes, remetendo-a àquele que o enviou (cf. MALBON, 2009, p. 141-146). Esta noção de "desvio" pode ser observada em Mc 1,38 no qual Jesus diz aos discípulos "Vamos para outros lugares, nas aldeias da redondeza, a fim de que, lá também eu proclame a Boa Nova. Pois foi para isso que eu saí”. Jesus, nesta perícope de Mc 1,35-39, está saindo de Cafarnaum, porém o v. 38 pode ser compreendido em duplo sentido: Jesus está saindo de Cafarnaum (v. 21.35), mas também saiu do Pai, que do batismo no Jordão afirma "tu és o meu Filho amado, em ti está todo meu agrado" (Mc 1,11). Do batismo, Jesus, passando pelo deserto, decide ir para a Galileia anunciar o Reino de Deus (cf. Mc 1,14-15).

Outro termo judaico que pode ser encontrado em Mc 14,61, no contexto da Paixão, para afirmar o título Filho de Deus, é o termo "Filho do Deus Bendito". O sumo sacerdote interroga Jesus, dizendo: "És tu o Messias, o Filho do Deus Bendito?” Jesus afirma: “Eu o sou”, mas parece se esquivar dizendo: "E vereis o Filho do Homem..." Os termos "Messias" (Mc 8,29) e "Filho de Deus" parecem relativizados mediante o título escatológico do "Filho do Homem".

O segundo título, anteriormente referido, Filho do Homem, não parece, segundo G. Van Oyen, uma descrição do papel Filho de Deus, mas um

\footnotetext{
${ }^{2}$ Van Oyen lembra que Ornias, um desses demônios, explica este conhecimento como o seguinte: «Nous, les démons, montons jusqu'au firmament des cieux et nous volons parmi les astres. Et nous entendons les jugements concernant les âmes des humains».
} 
cumprimento, uma espécie de autodesignação da parte Jesus (VAN OYEN, 2011, p. 112). Embora, o termo Filho do Homem signifique também a humanidade, a condição humana de Jesus, que sofrerá na Paixão, morrerá e, ao terceiro dia, ressuscitará, este caráter está acentuado nas narrativas que predizem a Paixão, a saber, Mc 8,31-33; 9,30-32; 10,32-34, reafirmado pela boca de Jesus em 14,41. Em Mc 2,28, na controvérsia acerca do dia de sábado (shabbat), Jesus afirma que o Filho do Homem é Senhor também do sábado. Outro sentido para o título Filho do Homem, que se aproxima muito de Dn 7,13-14, e pode ser identificado em Mc 13,26 e 14,62, diz respeito à escatologia, ao sentido apocalíptico de Jesus, no qual ele aparecerá glorioso, com poder, vindo com as nuvens do céu.

Destarte, o título Filho de Deus constitui uma qualificação a respeito de Jesus advinda de um ser humano, somente no ato final, ao pé da cruz, no momento da sua morte (Mc 15,39). Pode-se pensar que tais palavras correspondam, grosso modo, a uma profissão de fé cristã primitiva: “o centurião é o exemplo por excelência do pagão que se converte, reconhecendo Jesus como seu Deus” (VAN OYEN, 2011, p. 112). Compartilha-se tal convicção de Van Oyen, ao considerar que as palavras desse soldado pagão constatam a morte extraordinária de Jesus, aos moldes do servo sofredor de Is 52-53, pois ele carregou sobre si as iniquidades da humanidade e morre silenciosamente como um cordeiro entregue às mãos de seu tosquiador, pelo resgate de muitos (cf. Mc 10,45).

No que concerne à cristologia do Filho de Deus, pode-se dizer que somente o leitor implícito (ao qual a narrativa foi destinada) de Marcos consegue compreender a totalidade da história de Jesus. Nesse momento, em Mc 15,39, na morte de Jesus, os discípulos estão eclipsados nos bastidores do Evangelho. Logo em seguida, o narrador diz que algumas mulheres, dentre aquelas que serviam e seguiam Jesus, desde a Galileia, observavam de longe sua execução. A exclamação proveniente da boca do centurião possivelmente tenha alcançado todos aqueles que testemunhavam o martírio de Jesus. Tais palavras, no entanto, parecem não ter sido compreendidas por nenhum dos que compunham o cenário narrativo, “... salvo o leitor” (VAN OYEN, 2011, p. 112). O leitor de Marcos está situado tanto no início quanto no desfecho do Evangelho. Ele é o único a compreender a totalidade da história sobre Jesus e, por isso, compreende a força deste título cristológico que distingue Jesus de todos os outros personagens: ele é o Filho de Deus.

REINO DE DEUS

INTERAÇÕES, BELO HORIZONTE, BRASIL, V.12 N.21, P. 155-171, JAN./JUL. 2017 
O ponto de vista do reinado de Deus, da soberania divina assinalada na vida de Jesus, que corresponde em tudo, ao projeto e à vontade de Deus, constitui o objetivo central que encaminha Jesus a Jerusalém, ao encontro da cruz. Jesus vai para a Galileia para anunciar a iminência do Reino, Mc 1,14-15 e ensina as coisas do Reino e sobre o Reino (Mc 4,26-32), prometendo que alguns "não provarão a morte, sem antes tê-lo visto 'chegar com poder'." (Mc 9,1). O Reino é de Deus, mas Jesus o proclama, o prega 3 , o vivencia em gestos concretos, libertando e curando a todos os que estavam submetidos ao poder do Maligno. Assim dizendo:

A chegada da soberania de Deus significa que agora há acesso ao poder para restaurar a criação, reconduzindo os seres humanos a seu papel genuíno na ordem natural. Além disso, a soberania de Deus invoca uma nova ordem social, livre do tipo de opressão humana que caracteriza os governantes judeus e romanos. Desta forma, Jesus condena as autoridades por serem negligentes, destrutivas e opressoras. (RHOADS; MICHIE; DEWEY, 2002, p. 113).

O reinado de Deus, entendido como soberania de Deus, se revela implicitamente no relato da Paixão de maneira emblemática com Jesus que faz a vontade de Deus (Mc 14,36b), agindo conforme a soberania daquele que o enviou; ele celebra com seus discípulos a partilha do pão na última ceia (Mc 14,22-25), seu próprio corpo é oferecido como alimento; promete o vinho novo no Reino de Deus (Mc 14,25); se entrega às mãos dos perversos com a anuência e sob a vontade de Deus (Mc 14,41); seu caminho para o Calvário passa pelo projeto do Pai, que envia seu filho para cumprir sua vontade. Jesus leva essa vontade de Deus às últimas consequências, entregando-se pacifica e obedientemente à morte na cruz ${ }^{4}$.

A soberania de Deus também se mostra na ressurreição de Jesus, anunciada às mulheres que foram ao sepulcro (Mc 16,7) - por esse gesto, manifesta-se a certeza de que Jesus foi ressuscitado da morte e se faz presente na Galileia, primeiro lugar teológico da manifestação genuína da soberania de Deus por

\footnotetext{
3 Na opinião de Leonardo Boff, o Jesus histórico "não se pregou sistematicamente a si mesmo, nem a Igreja, nem a Deus; mas o Reino de Deus”. Nessa perspectiva, Jesus não anuncia que o Reino está próximo, mas que por sua presença e atuação o Reino já está perto (Mc 1,15). A ação libertadora de Jesus pode consistir em condição de possibilidade para a instauração do Reino de Deus. (BOFF, 2009, p. 26-27).

4 Embora o relato marcano evidencie em Mc 15,33 o clamor de Jesus na cruz, nas últimas palavras - "Eloi, Eloi, lema sabactâni” traduzido para "Meu Deus, Meu Deus, por que me abandonaste?”, esta passagem não dirime a doação de Jesus na cruz. Jesus recita o Salmo 22 referindo-se a Deus, pedindo para não ser abandonado, como expressão antecipatória da significação de sua morte. A morte, ou a angústia mediante a morte, constitui a possibilidade de uma ruptura radical entre o Filho e o Pai; Jesus e Deus. A morte poderia ser compreendida como hiato entre Jesus e seu Pai, hiato este nunca vivido entre o Filho e o Pai na relação intratrinitária.
} 
meio dos milagres e ensinos que lá protagonizou. A expressão "lá o vereis" (v.7) indica a certeza da glória de Jesus que será manifestada na Galileia: sua ressurreição constitui a plenipotência de Deus sobre seu Ungido - o Messias. Na perspectiva de E. Cuvillier, "para o leitor crente, este retorno à Galileia é sinônimo de um trabalho de releitura, de reinterpretação da existência de Jesus à luz do evento pascal: para ele, não há outro acesso ao Jesus da história que o Cristo da fé” (CUVILLIER, 2001, p. 312). Assim, a Galileia é lugar de reinício, sobretudo por causa da alegria que a ressurreição possibilita. Voltar a Galileia para ver o Ressuscitado e segui-lo é possibilidade de reinventar a fidelidade e entusiasmo do discipulado de Jesus (Mc 1,18).

\section{OUTROS PONTOS DE VISTA}

Outros pontos de vista emergem do relato da Paixão segundo Marcos (14,1 16,8): a unção em Betânia (Mc 14,3-9), por parte da mulher, cuja atitude seria sempre lembrada (ou "será contada", em grego: lalethésetai); a compreensão, ou a impossível compreensão da vontade humana versus a vontade de Deus (Mc 1432-42, a oração no Getsemani); a excepcional maquinação maligna das autoridades que, desde muito cedo, no evangelho de Marcos, procuram aniquilar Jesus, conduzindo-o à morte (Mc 14,43-44); em seguida, a conspiração de traição, fruto da incompreensão do traidor em relação a seu mestre Jesus (Mc 14,44-45, Judas chama Jesus de Rabi e o beija); o ponto de vista teológico e a perspectiva da ceia de Jesus (Mc 14,17-25), na instituição de um gesto profético de entrega antecipada da vida, significada no pão e no vinho (Mc 14,22-25) e compreendida de forma exemplar no altar da cruz (Mc 15,37); a incompreensão dos discípulos, seguida do abandono e da negação por parte de Pedro; a prisão de Jesus como negação do exercício de libertação de seus compatriotas; a confabulação perversa para condenar Jesus à morte; a execução de Jesus como máxima expressão da apatia e desprezo para com ele (Mc 14,6672); a exclamação de fé por parte do centurião, que proclama Jesus o Filho de Deus (15,39); o seguimento e o serviço das mulheres até o fim da vida de Jesus, ao pé da cruz (15,40-41), e o discipulado a partir do encantamento de uma figura quase final do evangelho, que é José de Arimateia, aquele que sepulta Jesus (15,42-46); por fim, a proclamação da ressurreição de Jesus e o encontro com ele na Galileia (16,1-7), tendo como final abrupto o medo e o silêncio das mulheres, designadas pela figura epifânica para anunciarem o Ressuscitado $(16,8)$. 
Os pontos de vista elaborados atenciosa e detalhadamente pelo narrador a respeito da vida de Jesus, desde sua unção em Betânia até o fim "enigmático" da trama, seguido do silêncio e do medo das mulheres seguidoras, formam o conjunto teológico da Paixão segundo Marcos, bem como o escopo, a finalidade pela qual ele narrou seu evangelho. Assim, consideramos que o narrador de Marcos dá um sentido teológico narrativo à cronologia dos últimos momentos da vida de Jesus, isto é, um significado à sua morte e à proclamação de sua ressurreição, lidas como verdades fundamentais do Evangelho.

Evidentemente, sem estes aspectos, presentes na narrativa da Paixão de Jesus em Marcos (Mc 14,1 - 16,8), não poderia ser anunciado o Evangelho como a Boa Nova do Jesus Ressuscitado. A narrativa da Paixão, em seu conjunto polifônico e harmonioso, dá sentido à vida de Jesus e também ao fato de sua ressurreição, pois o fundamento do Evangelho narrado é, necessariamente, a vida de Jesus, sua morte, mas principalmente o desfecho de tudo, a ressurreição.

FINAL ABERTO: MC 16,8

Pode-se encontrar no final de Marcos, em 16,8, em grego, as seguintes palavras: "kai oudení oudén eipan. Efobouto gár”, que podem ser traduzidas literalmente por "e a ninguém nada disseram; tinham medo, pois". Trata-se de um versículo aberto e abrupto. Contudo, após tal silêncio, provavelmente, as mulheres meditaram acerca dos fatos experimentados no seguimento de Jesus: sua prisão, morte e o anúncio da ressurreição, que dizia que ele estava vivo e que precederia seus discípulos na Galileia. Essa mensagem evidentemente não foi esquecida pelo pavor ou pelo medo que o narrador evidencia nessas personagens, do contrário o Evangelho do Ressuscitado jamais seria conhecido.

O fim do relato de Marcos parece possibilitar a observação do ponto de vista total do narrador, que se constitui abrupto, aberto e, ao mesmo tempo, possível de ser contado pelo leitor de hoje. Equivalendo, pois, a uma chave de leitura indispensável para o evangelho de Marcos, a narrativa de Mc 16,7-8 possibilita pensar que o leitor hodierno pode continuar o anúncio de Jesus, o Ressuscitado. Dessa maneira, o fim da narrativa de Marcos não pode ser pensado fechado, acabado ou saturado, mas aberto, inacabado e repleto de possibilidades para compreensão de Jesus e da mensagem da ressurreição - que nos atingem a todos ainda hoje. Essa abertura possibilita ver na narrativa da Paixão um caminho a ser percorrido pelo leitor que, ao fazê-lo, pode se reencontrar com Jesus de Nazaré. 
O final aberto do Evangelho como ponto de vista inusitado da teologia de Marcos, pode ser considerado uma continuidade do segredo acerca do personagem Jesus 5 , já que toda verdade comportada no evangelho não sana a curiosidade da fé humana a respeito de quem é Jesus. O mestre da Galileia, Jesus Nazareno, pode ser considerado em sentido mais amplo do que aquele que as notícias dão a conhecer: há uma reserva de sentido quanto a ele e à sua vida. O fim do Evangelho, permeado por medo e pavor, seguido de silêncio, pode, notadamente, significar que o mistério do Messias Jesus vai sendo desvelado na vivência do anúncio contínuo da boa notícia a seu respeito; boa notícia que nos diz que ele está vivo, ressuscitado, e que espera para ser contemplado por seus discípulos na Galileia. O que poderia ser entendido especificamente como tragédia ${ }^{6}$, no sentido clássico do termo, se transforma em possibilidade de catarse, de recomeço, como lugar de novas descobertas. Nesse sentido, Cássio Murilo Silva, considera que o final de Marcos pode ser entendido a partir de seu começo, Mc 1,1 "Início do evangelho de Jesus Cristo Filho de Deus". Para ele,

[...] além de ser o título do livro, tal versículo já exprime o que a obra em seu conjunto pretende ser: uma apresentação do surgimento e dos primeiros passos ('início') da Boa Nova de Jesus [...] várias foram as propostas que visavam a superar a dificuldade causada pelo insólito Mc 16,8, considerado a conclusão original (SILVA, 2007, p. 276).

O fim de Marcos: "E, tendo saído, fugiram do túmulo, pois tinham tremor e susto. E não disseram nada a ninguém, pois temiam”, considerado a conclusão original, pode ter soado incompleto para alguns copistas, que trataram de

\footnotetext{
5 C. Focant observa que em Marcos, ao invés de um segredo messiânico, haja uma cristologia "mística". Esta hipótese se afirma não como questão cognitiva acerca do Evangelho, mas pelo seguimento de Jesus Crucificado-Ressuscitado no percurso do Evangelho. (FOCANT, Camille. Une christologie de type 'mystique') (Marc 1,1-16,8). New Testament Studies, v. 55 (1), 2009, p.1-21. C. Focant chega a esta conclusão com base nos limites narrativos de Marcos (prólogo enigmático e final surpreendente), observando o desenvolvimento da trama em termos de ações do protagonista e as reações da resposta, e também o desenvolvimento da trama em termos de revelação e evolução dos modos como Jesus é representado. (Confira também MALBON, Elizabeth Struthers. History, theology, story: Recontextualizing Mark's 'Messianic Secret'. A characterization. In: SKINNER, Christopher W.; HAUGE, Matthew Ryan (Ed.). 5. ed. Characters studies and the Gospel Mark. London: Bloomsbury, 2014. p. 55.)

6 Por tragédia no sentido clássico do termo recorremos a Aristóteles em sua obra Poética. Para ele, é preciso distinguir (reconhecer) entre o horrível e o terrível. "[...] a tragédia é, por definição, a imitação de acções deste género (reconhecimento), pois que desse reconhecimento e dessa peripécia depende o ser-se infeliz ou feliz" (Poética 11, 1452a; 40-41). Em outro momento, afirma: "E os que, através do espectáculo, não produzem temor (tó foberón) mas apenas terror (tó Teratodesmónon), nada têm de comum com a tragédia: não se deve procurar na tragédia toda a espécie de prazer (édone,), mas a que lhe é peculiar" (Poética 14,1453b 8-11). Cf. ARISTÓTELES, 2008, p. 58.63.
} 
acrescentar (editorar) outro final7. "Um final que respondesse a objeção do gênero: 'Como as mulheres não contaram nada a ninguém? Se nós estamos sabendo hoje que Jesus ressuscitou, é porque, ao menos para alguém, elas narraram o acontecido!" (SILVA, 2007, p. 277). Consideramos, em parte, esta afirmação, sobretudo, no que concerne ao fato de que o autor (Marcos), já no início de sua obra, diz que ela não é tudo, mas só o início (arché). "Muitas coisas aconteceram e ainda vão acontecer. O resto vocês devem buscar na caminhada da Igreja..." (SILVA, 2007, p. 277) ${ }^{8}$. Por outra parte, consideramos que terminar em suspense seria um modo de passar adiante a necessidade de contar um final coerente para o Evangelho.

Desse modo, terminar uma narrativa com uma resposta em branco (PESCH, 1980, p. 99)9, em suspense (16,8), constitui, particularmente, um recurso literário muito estimulante para o leitor. A singularidade da conclusão de Marcos, afirma R. Pesch, "estimula a interpretação e não a reconstrução conjetural de suposições” (PESCH, 1980, p. 100). Isso significa que o leitor é provocado a tentar dizer o não-dito. Marcos não supõe uma resposta final para a intriga (Mc 15,40-16,8); antes, ele deixa a possibilidade de um final ao leitor em sua liberdade interpretativa. O silêncio marcano indica o convite dirigido ao leitor para que ele termine a narrativa buscando um desfecho em consonância com o relato narrado desde o começo (FOCANT, 2009, p. 599).

\section{A GALILEIA}

O ministério de Jesus, sua práxis na Galileia, tem início em Mc 1,14. A Galileia é o ambiente originário da ação messiânica de Jesus, o Filho de Deus. Em Cafarnaum, cidade dessa região, Jesus dá início à missão confiada pelo Pai. Lá, Jesus inaugura a exousía, o poder-autorizado por Deus $(1,21)^{10}$. É também no caminho à Galileia que os discípulos se encontrarão com o Vivente, o Ressuscitado (Mc 16,7). Segundo Marcos, Jesus precederá Pedro e os discípulos

\footnotetext{
7 Para aprofundar tal questão, ver AGUIRRE MONASTERIO; RODRIGUEZ CARMONA, 1994, p. 116-119. 8 Segundo Silva, o final "abrupto e estranho" de Marcos não tem nada de abrupto e estranho. "Antes, está altamente coerente com o que o autor já havia dito no título de sua obra: ele não quer narrar tudo minuciosamente, não quer esgotar a história. Quer apenas dizer como foi que tudo começou... o início”.

9 R. Pesch observa que, do ponto de vista estilístico, não é impossível que uma frase ou um relato, ou até mesmo um tratado ou livro em grego terminem com a expressão gar. $\mathrm{O} 32^{\circ}$ tratado de Plotino também tem seu desfecho com as expressões teleióteron gar.

10 Em Cafarnaum, num dia de sábado, Jesus foi à sinagoga e começou a ensinar (didáskein). As pessoas ficaram admiradas com o que ensinava, afirma Marcos. O verbo "ensinar" aparece 17 vezes no segundo evangelho. Jesus ensinava como quem tem autoridade-exousía. A atuação de Jesus era diferente da dos demais líderes, pois agia autorizadamente, ou seja, como alguém delegado por outro. Jesus era delegado por seu Pai. Sua ação não correspondia aos seus interesses pessoais, mas ao projeto de Deus, que consiste na salvação para todo aquele que crê.
} 
no caminho para a Galileia. "Lá o vereis, como ele vos disse", afirma o autor de Marcos (16,7). A Galileia não significa apenas o palco no qual Jesus inaugura a missão confiada a ele, mas é também o lugar no qual consuma sua revelação, como Ressuscitado, tal qual ele mesmo prometeu e anunciou nas narrativas da Paixão (SILVA; RABUSKE, 2011, p. 93) ${ }^{11}$.

Na perspectiva narrativa de Rhoads, Dewey e Michie,

A cena final indica a volta à Galileia, volta ao começo do relato, volta ao lugar onde a soberania de Deus havia sido bem recebida. A mensagem do jovem às mulheres no sepulcro com instruções para os discípulos para irem à Galileia sugere um voltar ao começo (RHOADS; DEWEY; MICHIE, 2002, p. 98-99).

A Galileia é lugar prototípico e escatológico, isto é, de gênese e consumação no segundo Evangelho. Na Galileia, na vivência da fé dos discípulos unidos em torno de Jesus, é possível encontrá-lo ressuscitado. Ele está presente na experiência de fé comunitária, na vida de oração e na partilha dos bens e das experiências entre os discípulos. A Galileia é lugar eclesial por excelência! (MAINVILLE; MARGUERAT, 2006, p. 5) ${ }^{12}$.

Do ponto de vista do narrador de Marcos, a Galileia pode ser considerada não apenas um espaço ou lugar político, mas o lugar da ressurreição, uma Galileia transfigurada, diferente daquela onde Jesus iniciou seu ministério messiânico. A Galileia que o segundo evangelho nos indica é, sem dúvida, um lugar teológico de anúncio, de encontro com Jesus, de abertura irrestrita à salvação que ele aponta e traz consigo. A Galileia prorrompe como a comunidade escatológica na qual todos os cristãos são convidados a participar a fim de proclamar Jesus, o Cristo, Vivente e Salvador.

\section{DIAKONIA}

\footnotetext{
${ }^{11}$ É possível encontrar em Marcos três relatos ou pré-anúncios da Paixão, Morte e Ressurreição: Mc 8, 31; 9,31; 10, 33-34. Segundo os autores, "Os três anúncios da Paixão e Ressurreição não são meras profecias de Jesus acerca de seu próprio futuro, mas indicam o objetivo final da caminhada: chegar às últimas consequências do anúncio do Reino. Em Marcos, os três anúncios estruturam o caminho de Jesus para Jerusalém. No primeiro anúncio, Jesus resiste à tentativa dos discípulos de fazê-lo desistir de seu objetivo. Pedro fala e é repreendido em nome dos discípulos”.

12 De acordo com Mainville e Marguerat, a narrativa da aparição de Jesus às mulheres, proposta por Mateus (28,9-10) e não explicitada o suficiente em Marcos $(16,7)$, por causa do fim abrupto $(16,9)$, não pode ser classificada nem na categoria missionária, nem na catequética, como propõem os autores. A menção sobre a Galileia em Marcos teria como única função atribuir ao Ressuscitado a responsabilidade pelos primórdios eclesiais na Galileia. Deste modo, quando Marcos menciona a precedência de Jesus no caminho à Galileia pode-se entender a importância eclesial daquele lugar.
} 
O ponto de vista diaconal também se destaca ao longo da unidade narrativa de Mc 14,1 - 16,8. Alguns gestos demonstram apreço pelo serviço a Jesus. Cinco momentos podem ser destacados na unidade narrativa como paradigmas diaconais. A primeira cena refere-se ao início do relato da Paixão, no qual a mulher unge Jesus para a morte, em Betânia (Mc 14,3-9). A segunda cena concerne ao homem com a bilha de água que indica aos dois discípulos de Jesus o local preparado para a última ceia em Mc 14,13-16. A terceira cena em Mc 15,21, na qual Simão Cireneu é obrigado a ajudar Jesus a carregar sua cruz até o Calvário. A quarta alusão diaconal, atrelada ao seguimento, está em Mc 15,4041, explicitamente narrado. Por fim, a quinta indicação concerne ao serviço prestado por José de Arimateia, que pede a Pilatos o corpo de Jesus a fim de sepultá-lo $(15,43)$.

No primeiro momento, a mulher que unge Jesus (Mc 14,3-9), sob o ponto de vista do narrador, realiza um gesto diaconal intrinsecamente associado ao que será proclamado, narrado e contado (lalethésetai) em Mc 14,9. A narração da diakonia da mulher em Betânia está associada à proclamação, como "se a narração se tornasse anúncio evangélico, mas o anúncio evangélico é que provocará a narração" (DELORME, 1997, p. 370). Não se atém à questão do que vem antes ou depois, o oportuno é dizer que o gesto diaconal da mulher anônima em Betânia será contado em sua memória (mnemósynon). Da mesma forma, a Paixão de Jesus será narrada a todas as gerações em favor de sua memória. Por isso, o serviço, a diakonia da mulher, para o narrador do segundo Evangelho, constitui condição para a memória proclamada do Evangelho; a diakonia ${ }^{13}$ neste Evangelho constitui-se em conteúdo da Boa Nova.

O segundo momento refere-se ao homem com a bilha de água, em Mc 14,1315. Aqui, o inusitado é pensar a presença de um homem neste contexto feminino, o que na opinião de D. Marguerat parece uma "anomalia social" (MARGUERAT, 2012, p. 118). Já para J. Gnilka, seguramente "podia encontrarse em todo momento em Jerusalém pessoas que levavam água da fonte de Siloé" (GNILKA, 2005, p. 273) ${ }^{14}$ para suas casas. D. Marguerat não concorda com esta hipótese de J. Gnilka, da qual diz que poderia ser de fato um homem realizando uma ação reservada às mulheres (Jo 4,28). A presença de um homem serve

${ }^{13}$ A diakonia de Jesus ao longo do Evangelho, curando, expulsando demônios e ensinando pode ser percebida, com mesma intensidade, no ato da mulher que o unge para a morte. Da mesma forma que ela será lembrada, Jesus também não será esquecido, pois o que ele realizou se constitui na suma doação de sua vida na cruz, sem restrição alguma.

14 J. Gnilka se preocupa muito mais com o detalhe sobre quem pede a preparação da sala de jantar que propriamente com quem é exortado a arrumá-la, conforme Jesus indica. Para Gnilka, o mais importante é situar na cena a figura do didáskalos. 
muito mais à narrativa que propriamente aos dados históricos. O que aqui interessa é o plano narratológico; a questão adequada é o efeito exercido no leitor, sobretudo pelo detalhe anedótico em um momento dramático. A questão gira em torno do conhecimento prognóstico de Jesus (em sentido de presciência) ${ }^{15}$.

O terceiro momento está presente explicitamente em 15,21: Jesus estava levando sua cruz para o Calvário, quando aparece na cena um homem, chamado Simão Cireneu, pai de Alexandre e Rufo, que ajuda Jesus a carregar a cruz. Ele exerce um papel decisivo, tornando-se, mesmo que por imposição, solidário com Jesus em seu suplício. No ponto de vista de Marcos, há uma diakonia imposta, mesmo porque não se pode afirmar que foi uma iniciativa própria de Simão.

No quarto momento, Mc 15,40-41 o narrador alude às mulheres, Maria Madalena e Maria, a mãe de Tiago Menor e de Joset, e Salomé, que observavam de longe (Mc 15,40). O leitor é conduzido a decifrar o ponto de vista do narrador: a diakonia e o seguimento, ou seja, a diakonia aos necessitados e o seguimento do mestre até as últimas consequências. Ao mesmo tempo, o leitor "que segue a história do começo até este ponto, pode por um instante se identificar com elas" (STANDAERT, 2002, p. 76). Para elas, viver a akolouthia, o seguimento, significa acompanhar o mestre aonde ele for. O narrador, ao inseri-las no cenário da morte, quer levar o leitor a compreender o verdadeiro sentido do discipulado: tomar a cruz e seguir o mestre ${ }^{16}$. Do ponto de vista do narrador, todos são chamados à mesma experiência destas mulheres, seguir a Jesus aonde ele for.

O quinto momento refere-se a José de Arimateia. Ele elucida, com sua atitude no interior da unidade narrativa, o ponto de vista da perfeita diakonia. José, homem nobre e de posição social, se coloca a serviço de Jesus (Mc 15,43). Sendo ele um homem influente, consegue a permissão de sepultar o homem assassinado na cruz (Mc 15,46). José de Arimateia parece justificar sua

\footnotetext{
$15 \mathrm{O}$ serviço prestado pelo homem com a bilha sobre a cabeça pode constituir-se em um convite à reflexão: todo discípulo de Jesus é chamado ao serviço. Embora não se saiba a identidade verdadeira daquele homem, e se ele pertenceria ao círculo dos discípulos de Jesus, o mais curioso é que ele põe-se a serviço de Jesus de modo exemplar, a ponto de servir sua própria casa como sala de jantar para a realização da última ceia.

${ }^{16} \mathrm{O}$ ponto de vista do seguimento e do serviço - akolouthia e diakonia - permite ao leitor visualizar o seguimento do caminho de Jesus a Jerusalém como o principal caminho: aquele que conduz à cruz. A morte de Jesus pode ser interpretada ainda como o serviço de Jesus, a realização da soberania de Deus. O discípulo é convidado pelo mestre Jesus a segui-lo. Muitos serão convidados pelo caminho, mas nem todos chegarão ao Calvário com Jesus.
} 
diakonia com a experiência, não descrita, mas pressuposta, de um discipulado. Discipulado não explícito, haja vista que ele ocupava cargo de destaque no Conselho do Sinédrio. Se ele tivesse se colocado no caminho de Jesus teria se tornado motivo de escândalo para muitos. Ninguém compreenderia o sentido de um notável homem da religião judaica estar no seguimento de Jesus de Nazaré, um galileu.

\section{O FEMININO}

As mulheres exercem um papel surpreendente no relato da Paixão, papel não exercido oficialmente no decorrer dos capítulos de $1-13$, com exceção, talvez, da sogra de Pedro, que depois de curada põe-se a serviço de Jesus e dos discípulos (Mc 1,29-31); e da mulher siro-fenícia, que dialoga com Jesus e insiste para que ele também sirva com as migalhas da salvação os pagãos, que como cães também poderiam comer da mesa dos filhos (7, 24-30). É importante lembrar-se da mulher que ungiu Jesus em Betânia, em 14,3-9. Uma questão é digna de nota: as mulheres, mencionadas nos capítulos 15 e 16 são nomeadas pelo narrador, podendo isso ser considerado um diferencial extraordinário dessas mulheres, pois o narrador as retira da marginalidade inominável $(15,40$. 47 e 16,1). Elas são chamadas pelo nome, pois executam no Evangelho um importante papel. Diferentemente de Herodíades, a primeira mulher a ser mencionada na narrativa, que pede a cabeça de João como prêmio $(6,14-29)$. Seu nome é lembrado de forma antitética.

Maria Madalena, Maria, a mãe de Tiago Menor e de Joset, além de Salomé, como são nomeadas, entram em cena três vezes. Este ponto de vista se torna nodal, pois é uma questão inaudita a presença de mulheres num contexto androcêntrico, amplamente destinado ao masculino (RHOADS; DEWEY; MICHIE, 2002, p. 182) ${ }^{17}$. Isso constitui o diferencial da narrativa de Marcos: ao apresentar as mulheres nas cenas finais do evangelho, o narrador indica que a presença delas vai, em um crescente teológico, se abrindo ao mistério de Deus desde a contemplação de Jesus morto, no Calvário (Mc 15,40), passando pelo sepultamento (Mc 16,1) e, sobretudo, pelo medo, que não é um retrato de menosprezo às mulheres (Mc 16,7-8), mas assinala a humanidade em sua existência cotidiana (Cf. CUVILLIER, 2002, p. 312) e a sensibilidade delas mediante o indizível mistério de Deus.

\footnotetext{
17 Rhoads, Dewey e Michie colocam as mulheres no rol dos personagens secundários. No caso das três mulheres mencionadas por Marcos, no final do relato da Paixão elas deixam o elenco dos personagens relativos e passam ao elenco dos protagonistas, pois exercem uma influência no relato.
} 
O silêncio e o medo $(16,8)$, últimas palavras do narrador de Marcos, não indicam a negatividade da presença de tais mulheres no cenário do sepulcro. A ação de Deus, atuante no mistério da ressurreição de Jesus como fato inusitado e a mensagem acerca do Vivente enternecem seus corações. Elas, porém, não dizem nada a ninguém, porque tinham medo; medo que as silenciou diante do sepulcro. Contudo, tal medo não as impediu de procurar a Jesus. O diferencial dessa presença no sepulcro não é atenuado pelo medo; antes, o medo retrata que o mistério é sublime e causa espanto, mesmo nos corações daquelas que, tendo seguido e servido a Jesus desde a Galileia, tinham-lhe fé.

\section{O SERVO SOFREDOR}

Na busca de definir o itinerário teológico do narrador e seu ponto de vista final, pode-se afirmar que Marcos bebeu nas fontes de Isaías a teologia do servo sofredor, o Servo do Senhor, alusão à teologia do terceiro-Isaías, sobremaneira Is 53,7. A cristologia de Marcos constitui produto refinado da percepção e leitura do servo sofredor que se entrega piamente (dídōmi) à morte, sofrendo e morrendo por muitos (Mc 10,45). Baseia-se essa consideração na hipótese de que o narrador de Marcos tenha se inspirado no horizonte teológico de Isaías, sobretudo no cântico do servo de YHWH, que sofre resolutamente: "Ele foi oprimido e afligido, mas não abriu a sua boca; como um cordeiro foi levado ao matadouro, e como a ovelha muda perante os seus tosquiadores, assim ele não abriu a sua boca" (Is 53,7). Jesus mesmo afirma, enfaticamente, em Mc 14,41: "Ainda dormis e descansais? Basta! Chegou a hora! Vede, o Filho do Homem está sendo entregue às mãos dos pecadores”. Deste modo, em Mc 15,39, o centurião que afirma a filiação divina de Jesus em sua morte, representa os povos vizinhos, que testemunham o acontecido com o servo piedoso que sofre, mas que obtém o triunfo de Deus, pois cumpre com diligência o que o Senhor lhe ordenou.

A mensagem sobre o sofrimento de Jesus, no evangelho de Marcos, assim como o sofrimento do servo de $\mathrm{YHWH}$, em Isaías, parece maior e significantemente mais importante que o próprio triunfo de ambos. Contudo, a mensagem positiva e de esperança constitui a essência de ambos os textos. Jesus é visto como servo sofredor e obediente a Deus na ótica de Marcos; é o servo que se entrega, desde o princípio da narrativa da Paixão, às mãos dos malvados e, seguramente, às mãos salvíficas de Deus, o Pai. A exclamação fiducial “Abbá (ó Pai)! Todas as coisas são possíveis para ti: afasta de mim este 
cálice; [...], porém, não o que eu quero, mas o que tu queres" (Mc 14,36), corresponde ao desejo de cumprir tal vontade e não se furtar à sua própria. $\mathrm{O}$ filho Jesus se entrega nas mãos do Pai cumprindo os desígnios da soberania de Deus, e não a sua própria glória. O ponto de vista final de Marcos ressalta Jesus, Filho de Deus, que se faz servo para a salvação de muitos, entregando a própria vida aos discípulos (Mc 14,22), oferecendo-lhes o cálice da aliança derramado por muitos (Mc 14,24) e estando prestes a beber o cálice do martírio (Mc 14,36). A morte de Jesus, então, se faz motivo de dispersão dos discípulos; sua profecia diz: "Ferirei o pastor e as ovelhas serão dispersas" (Mc 14,27). Contudo, o servo de Deus, crucificado-ressuscitado, irá adiante dos seus, na Galileia: "Mas depois que eu ressuscitar, eu vos precederei na Galileia” (Mc 16,7b) - esta é a grande certeza de fé no ressuscitado, mencionada explicitamente por Jesus, bem como nos anúncios de sua Paixão, no decorrer do segundo Evangelho (Mc 8,31; 9, 31; 10, 33-34).

\section{CONSIDERAÇÕES FINAIS}

No relato da Paixão (Mc 14,1 - 16,8), pôde-se notar que diversos são os pontos de vista do narrador, o autor implícito do Evangelho: o ponto de vista do Filho de Deus e Filho do Homem, o ponto de vista do Reino de Deus, e, enfim, o final aberto de Marcos, a Galileia, a diakonia de alguns personagens que corroboram a teologia do entregar-se de Jesus na cruz, a presença das mulheres no cenário da morte de Jesus. Esses pontos de vista do narrador, amalgamados no relato, permitem evidenciar a cristologia elaborada de Marcos, que tem como escopo o conhecimento de Jesus de Nazaré, crucificado-ressuscitado.

A narrativa da Paixão em Marcos propõe ao leitor real (o que lê Marcos hoje) um encontro com o Filho de Deus, Jesus Cristo, que se entrega na cruz para o resgate de muitos. Nesse sentido, pode-se considerar que a vida de Jesus corresponde à "epifania secreta, e somente a proclamação da cruz e da ressurreição revelam, devida e justamente, Jesus no Evangelho” (AZEVEDO, 2002, p. 125). Deste modo, a cristologia de Marcos revela personagens que contribuem para a elaboração do personagem protagonista, Jesus de Nazaré. O ponto de vista fundamental de Marcos consiste em relatar que na morte de Jesus e na soberania do Reino de Deus, anunciado por ele, se revela a entrega e diakonia do servo sofredor, que, piedosamente, se doa para resgatar a muitos.

\section{REFERÊNCIAS}

INTERAÇÕES, BELO HORIZONTE, BRASIL, V.12 N.21, P. 155-171, JAN./JUL. 2017 
AGUIRRE MONASTERIO, R.; RODRIGUEZ CARMONA, A. Evangelhos sinóticos e Atos dos Apóstolos. São Paulo: Ave Maria, 1994.

ARISTÓTELES. Poética. Lisboa: Edição da Fundação Calouste Gulbenkian, 2008.

AZEVEDO, Walmor de Oliveira. Comunidade e missão no Evangelho de Marcos. São Paulo: Loyola, 2002.

BOFF, Leonardo. Jesus Cristo libertador: ensaio de Cristologia crítica para o nosso Tempo. 20. ed. Petrópolis: Vozes, 2009.

CUVILLIER, Élian. L'Évangile de Marc. Genève: Labor et Fides, 2002.

DELORME, Jean. Évangile et récit: la narration evangélique en Marc. New Testament Study, n. 43, 1997, p. 367-384.

GNILKA, Joachim. El Evangelio según san Marcos: Mc 1-8,26. v. 1. 5 ed. Salamanca: Sígueme, 2005.

El Evangelio según san Marcos: Mc 8,27-16,20. v. 2. 5 ed. Salamanca: Sígueme, 2005.

El Evangelio según san Marcos. v.I. Salamanca: ediciones Sigueme. 1986.

FOCANT, Camille. Une christologie de type 'mystique' (Marc 1,1-16,8). New

Testament Studies, v. 55 (1), 2009, p.1-21.

MAINVILLE, Odette; MARGUERAT, Daniel. Ressurreição: o pós-morte no mundo antigo e no Novo Testamento. Ciberteologia: Revista de teologia e cultura. São Paulo, n. 4, p. 1-8, mar./abr., 2006.

MALBON, Elizabeth Struthers. Mark's Jesus: characterization as Narrative Christology. Waco TX: Baylor University Press, 2009.

MALBON, Elizabeth Struthers. History, theology, story: re-contextualizing Mark's 'Messianic Secret'. A characterization. In: SKINNER, Christopher W.; HAUGE, Matthew Ryan (Ed.). 5. ed. Characters studies and the Gospel Mark. London: Bloomsbury, 2014.

MARGUERAT, Daniel. À la recherche de l'intrigue: une lecture de la Passion (Mc 14 et Lc 22). In : MARGUERAT, Daniel; WÉNIN, André. Saveurs du récit biblique. Genève: Labor et Fides, 2012.

PESCH, Rudolf. Il Vangelo di Marco I: introduzione e commento ai capp. 1,1-8,26. Brescia: Paideia, 1980.

RHOADS, David; DEWEY, Joanna; MICHIE, Donald. Marcos como relato: introducción a la narrativa de un evangelio. Salamanca: Sígueme, 2002.

SEGAllA, Giuseppe. A cristologia do Novo Testamento. São Paulo: Loyola, 1992. SILVA, Cássio Murilo Dias. Metodologia de Exegese Bíblica. 3. ed. São Paulo: Paulinas, 2009. 
SILVA, Cássio Murilo Dias; RABUSKE, Irineu. Evangelhos e Atos dos Apóstolos: novíssima tradução dos originais. São Paulo: Loyola, 2011.

STANDAERT, Benoit. Raconter la résurrection un paradoxe narratif. In: BIERINGER, R.; KOPERSKI, V.; LATAIRE, B. (ed.). Resurrection in the New Testament.

Festschrifit J. Lambrecht; Leuven: University Press, 2002.

VAN OYEN, Geert. Lire l' évangile de Marc comme un roman. Bruxelles: Lessius, 2011.

VITÓRIO, Jaldemir. Análise narrativa: primeiros passos de um método. São Paulo: Paulinas, 2016. 